ARCHIVO ESPAÑOL DE ARTE, LXXXIII, 331

JULIO-SEPTIEMBRE 2010, pp. 213-234

ISSN: 0004-0428

\title{
EL PABELLÓN ESPAÑOL DE 1939: UN PROYECTO FRUSTRADO PARA LA EXPOSICIÓN INTERNACIONAL DE NUEVA YORK ${ }^{1}$
}

\author{
POR \\ IDOIA Murga CASTRO \\ Instituto de Historia, CCHS, CSIC
}

El Pabellón español de la Exposición Internacional de Nueva York de 1939 fue un proyecto aprobado por el Gobierno de la II República y que, debido al desenlace de la Guerra Civil española, nunca llegó a inaugurarse. En este artículo se recoge la documentación inédita acerca de los artistas, las obras y los responsables políticos que se vieron involucrados en estos planes truncados, el último gran encargo institucional republicano y la llamada de socorro a la comunidad internacional.

Palabras clave: Pabellón español; 1939; Guerra Civil española; Exposición Internacional de Nueva York; Relaciones internacionales; Arte y política; Exilio.

\section{THE 1939 SPANISH PAVILION: A FAILED PROJECT FOR THE NEW YORK WORLD'S FAIR}

The Spanish Pavilion in the New York World's Fair of 1939 was an approved project by the Spanish Republican Government, which was never opened due to the end of the Spanish Civil War. This study gathers unpublished information about the artists, the works, and the politicians in charge of these frustrated plans. This was one of the last institutional assignments of the Second Republic and a coll for help to the international community.

Key words: Spanish Pavilion; 1939; Spanish Civil War; New York World's Fair; International Affairs; Art and Politics; Exile.

\footnotetext{
${ }^{1}$ Este artículo se ha realizado en el marco del programa FPU del Ministerio de Educación, del proyecto de investigación del MICINN Arte y artistas españoles dentro y fuera de la dictadura franquista (PN ref. HAR2008-00744) y durante una estancia como Visiting Scholar en la Columbia University de Nueva York. Igualmente me gustaría agradecer su ayuda, en especial, a Miguel Cabañas Bravo, así como a Lynn Garafola, Luis Sacristán e Isabel Argerich.
} 


\section{Introducción}

Algunos de los acontecimientos más importantes que tuvieron lugar en el campo artístico durante los años de la Guerra Civil española han sido descubiertos, en los últimos años, con un cierto aire novelístico. Si a finales de los ochenta el azar descubría en los almacenes del Museo Nacional de Arte de Cataluña una parte de las obras expuestas en el Pabellón español de la Exposición Internacional de París de 1937, la localización de unos frescos de Luis Quintanilla para el Pabellón español de la Exposición Internacional de Nueva York de 1939 en un cine porno de la ciudad estadounidense sólo añadía más morbo al asunto. Sin embargo, así como profundos estudios han terminado por revelar la práctica totalidad de los detalles de la participación española en París, parecía que la recuperación de los mencionados frescos por la Universidad de Cantabria sólo descubría la punta de un iceberg acerca de una gran laguna en nuestra historia del arte más reciente: aquélla relacionada con la anunciada, pero nunca materializada, participación de España en la New York World's Fair de 1939.

El Gobierno de la República, en plena guerra, cada vez se veía más amenazado por el avance franquista y, a pesar de ello, trató de priorizar las labores de propaganda en el exterior que llamaran la atención acerca de la legalidad de su causa, con el objetivo de conseguir apoyos para combatir el avance del fascismo en España. Para ello, no dudaron en organizar la participación española en la Exposición Internacional de las Artes y Técnicas de la Vida Moderna, que tuvo lugar en el París de 1937. Concebido como una obra de arte total en la que se combinaban las artes plásticas, las artes escénicas, las muestras de artesanías populares y la arquitectura racionalista, la función principal del Pabellón español era la de servir de escaparate de la tradición y la vanguardia en la cultura española y, sobre todo, la de difundir las medidas implantadas por el Gobierno republicano ${ }^{2}$. Tras su inauguración el 12 de julio de 1937, el éxito de la unión de arte y propaganda, así como la buena acogida del público, llevaron a aprobar la configuración de un nuevo proyecto para el Pabellón español, esta vez para aprovechar el siguiente acontecimiento internacional en el ámbito cultural: la Feria Mundial de Nueva York de 1939.

\section{La gestación del proyecto. The World of Tomorrow}

La New York World's Fair de 1939 fue convocada desde el 15 de junio de 1936, cuando el Presidente de los Estados Unidos, Franklin Roosevelt, invitó a su participación en el Public Art $n{ }^{\circ} 105$. Su objetivo era conmemorar los ciento cincuenta años de la llegada al poder de George Washington como primer presidente del país. Su lema, The World of Tomorrow (El Mundo del Mañana), aludía a su inmediatamente fracasada intención de convertirse en un nexo de unión de los países en paz, en un momento en el que las tensiones internacionales entre ideologías contrarias estallarían enseguida en una nueva gran guerra, de la que España no era más que el primer acto del drama, el conejillo de indias que el resto del mundo observaba ${ }^{3}$. Así lo aseguraba el

\footnotetext{
${ }^{2}$ Sobre el Pabellón español de 1937 véanse: FreEdBerg, Catherine B.: The Spanish Pavilion at the Paris World's Fair of 1937, Nueva York, Garland Publishing, 1986. Martín Martín, Fernando: El pabellón español en la Exposición Universal de París en 1937, Sevilla, Universidad de Sevilla, 1983. Alix TruebA, Josefina: Pabellón español. Exposición Internacional de París, 1937 [cat. exp.], Madrid, MNCARS-MCU, 1987. Art contra la guerra: entorn del Pavelló Espanyol a l'Exposició Internacional de París de 1937 [cat. exp.], Barcelona, Palau de la Virreina y Ayto. Barcelona, 1986.

3 Whalen escribía lo siguiente a este propósito en el prefacio del Book of Nations que editó la organización de la Feria en 1939: "The nations represented at the New York World's Fair are making important contributions to our individual knowledge and progress and toward developing a better understanding among the people of the world. [...] It promises understanding, friendship and world trade, and when we have these, we will have lasting peace and happiness
} 
propio Roosevelt en un discurso pronunciado delante de los diplomáticos extranjeros con ocasión de la colocación de la primera piedra de la Exposición, el 30 de junio de 1938:

Estas manifestaciones -agrega el presidente- no pueden dejar de desarrollar el pensamiento, la cultura y las actividades comerciales e industriales, o sea todo el mecanismo de intercambio material y espiritual que es imprescindible a las naciones modernas. Con toda razón se dice que es imposible odiar al hombre que se conoce. Por consiguiente la Exposición de Nueva York será un símbolo de paz mundial y constituirá un paso adelante en el camino de la paz ${ }^{4}$.

La primera invitación oficial que el gobierno estadounidense envió al de la II República española está indicada en una ficha conservada en Nueva York, fechada el 16 de noviembre de 1936 . De nuevo, el 25 de agosto de 1937 se envió una segunda invitación oficial a través de José Giral como Ministro de Estado ${ }^{6}$. En ella se nombraba a Grover A. Whalen como Comisario General de la Feria, que sería quien llevaría las gestiones sobre España directamente con Fernando de los Ríos, embajador español en Washington y cabeza del proyecto desde el primer hasta el último momento. Hacía poco más de un mes que, tras mucho retraso y una accidentada preparación, se había inaugurado el Pabellón español de la Exposición Internacional de París de 1937, que se clausuraría a finales del mes de noviembre, del que era comisario José Gaos y que coordinaba el Director General de Bellas Artes, Josep Renau.

Sin embargo, la respuesta de España se hizo esperar ${ }^{7}$, pues no fue hasta más de un año después de la recepción de la invitación americana, el 1 de septiembre de 1938, cuando De los Ríos transmitió al almirante W. H. Standley la resolución definitiva del gobierno republicano ${ }^{8}$. Finalmente, el nuevo Gobierno de Negrín había aceptado participar en Nueva York, siendo el Ministro de Instrucción Pública (en adelante, MIP) el cenetista Segundo Blanco y encabezando la Dirección General de Bellas Artes (en adelante, DGBA) Francesc Galí. La noticia era avanzada por The New York Times:

Despite the civil war and a future which outsiders consider is so uncertain for the Loyalists, the Spanish Government is preparing to open a pavilion at the New York

in the world" (Book of Nations, Nueva York y Washington, Burland Printing Company, 1939, p. 9). Las críticas no tardaron en llamar la atención sobre el uso propagandístico de los medios artísticos: "Art has been put to the uses of propaganda at the Fair to an extent which I can only barely indicate" (PEALE Bishop, John: "World's Fair Notes", The Kenyon Review, vol. 1, n. ${ }^{\circ}$ 3, Kenyon College, Nueva York, verano de 1939, p. 247).

4 "Nuevo discurso pacifista de Roosevelt", La Vanguardia, Barcelona, 1-7-1938, p. 6.

${ }^{5}$ Formulario completado con las fechas de invitación y aceptación de la participación de España en la Feria Mundial de Nueva York. The New York World's Fair 1939 and 1940 (NYWF 1939-1940). Caja 1503, carpeta 1. New York World's Fair 1939-1940 records. Manuscripts and Archives Division. The New York Public Library. Astor, Lenox and Tilden Foundations (en adelante, NYPL).

${ }^{6}$ Carta de Walter C. Thurston al Secretario de Estado, Washington, 25-8-1937. Lleva adjuntos dos anexos: "Enclosure No. 1 to despatch No. X-204 of August 26, 1937, from Embassy at Valencia, Spain" y "Enclosure No. 2 to despatch No. X-204 of August 26, 1937, from Embassy at Valencia, Spain”. NYWF 1939-1940. C. 319, carp. 2. NYPL.

7 Quizás por desavenencias existentes entre la organización de la Exposición neoyorquina y el Bureau International des Expositions, del que España era miembro tras el acuerdo del 22 de noviembre de 1928, y que regulaba los reglamentos de las Exposiciones Universales. Véanse las cartas entre el presidente del BIE y Whalen de fechas 4-11-1937, 17-12-1937, 22-11-1937, 3-1-1938, 22-11-1938, y su comunicación a la Embajada española en París y el Ministerio de Estado español, con fechas: 10-11-1937, 21-12-1937, 29-12-1937, 30-12-1937, 19-1-1938, 26-1-1938, 11-6-1938, 2211-1938, 23-11-1938, 28-11-1938, 1-12-1938, 8-12-1938. Expediente "Exposición Universal de Nueva York 1939". Archivo General de la Administración (AGA), Sección Asuntos Exteriores (Secc. AAEE), Caja AGA 54/11073.

8 Carta de De los Ríos a Standley, Washington, 1-9-1939. NYWF 1939-1940. C. 1503, Carp. 1. NYPL. 
World's Fair next April and intends to keep it going throughout the exposition's entire six months, it was learned today.

It will have to be a rather moderate effort, quantitatively, because the government cannot afford to turn aside much money under the present circumstances?

El contrato entre el gobierno de la República española, a través de Fernando de los Ríos, y la New York World's Fair se firmó el 9 de septiembre de $1938^{10}$. Se decidió ocupar el espacio GQ-7, de unos cien mil pies cuadrados brutos - unos tres mil metros cuadrados-, que se dividirían en un máximo de cinco mil pies cuadrados en la planta baja cubierta y otros tantos en una entreplanta o en un primer piso. Además, la Feria nombró a Albin Johnson como Comisario para España, quien se encargaría de las gestiones específicas del Pabellón. Igualmente, a mediados de septiembre, el gobierno español designó a dos arquitectos neoyorquinos como "arquitectos supervisores", mediadores de sus obras: Ralph Pomerance y Simon Breines, del estudio de arquitectos Pomerance \& Breines, ubicado en la calle 49 de Manhattan ${ }^{11}$.

Poco después, por decreto del 12 de octubre de 1938, Negrín nombraba a tres arquitectos con cargos para la participación española en la Exposición Universal de Nueva York de 1939. Así, Manuel Sánchez Arcas se convirtió en Presidente del Comité Interministerial de Dirección de la Participación, mientras que Roberto Fernández Balbuena recibió el cargo de Comisario General y Jesús Martí Martín, el de Comisario Adjunto y el de Arquitecto del Pabellón de España ${ }^{12}$.

Tanto Sánchez Arcas como Fernández Balbuena habían ocupado cargos importantes en la política artística republicana. El primero, militante comunista, había formado parte de la primera Junta para la Defensa del Patrimonio - futura Junta de Incautación y Protección del Tesoro Artístico-, creada en julio de 1936. Igualmente, había sido Vicepresidente de la Junta Central del Tesoro Artístico (en adelante JCTA) desde julio de 1937 y Subdirector de Propaganda, dependiente del Ministerio de Estado, desde abril de 1938. Por su parte, Fernández Balbuena había sido designado Delegado en Madrid de la DGBA en diciembre de 1936, Presidente de la Junta Delegada del Tesoro Artístico en Madrid (en adelante JDTAM), en enero de 1937, Director Interino de la Escuela Superior de Bellas Artes, y Subdirector Interino del Museo del Prado, en enero de $1938^{13}$. En ese momento, se encontraba en Suecia, impartiendo conferencias acerca del Tesoro Artístico español durante el conflicto, que le organizó la embajadora española, Isabel Oyarzábal de Palencia ${ }^{14}$.

Por otro lado, Jesús Martí también llevaba a sus espaldas una amplia trayectoria de colaboración con las medidas del gobierno republicano en materia de protección del patrimonio español.

\footnotetext{
9 "Spanish Loyalists Plan Fair Exhibit", The New York Times, Nueva York, 1-9-1938, p. 23.

${ }_{10}$ Contrato entre España y la New York World's Fair, Nueva York, 9-9-1938. NYWF 1939-1940. C. 1503, carp. 1. NYPL.

${ }^{11}$ Carta de Knox F. Burnett, Ingeniero de la exposición, a W. H. Standley, Nueva York, 12-9-1938. Carta de Standley a Wharton Green, Director de la participación de los gobiernos extranjeros, Nueva York, 20-9-1938. NYWF 1939-1940. C. 319, carp. 2. NYPL. Ralph Pomerance (Nueva York, 1908-1995) y Simon Breines (Nueva York, 19062003) trabajaron juntos en la firma entre 1935 y 1993, y llevaron a cabo más de cuatrocientos proyectos. Entre ellos, colaboraron con el arquitecto Sven Marelius en el Pabellón Sueco de la Feria. Véanse: "Ralph Pomerance, Architect, 87", The New York Times, Nueva York, 25-8-1995, p. 7. PACE, Eric: "Simon Breines, 97, an Architect and a Critic of Hurried Projects", The New York Times, Nueva York, 25-9-2003, p. 10.

12 Gaceta de la República, n. ${ }^{\circ}$ 287, 14-10-1938, p. 287.

13 Véase CABAÑAs Bravo, Miguel: "La II República española ante la salvaguarda del patrimonio artístico y la guerra civil" en Arte salvado. 70 aniversario del salvamento del patrimonio artístico español y de la intervención internacional [cat. exp.], Madrid, SECC, 2010.

14 Telegrama del Subsecretario de propaganda a Fernández Balbuena, Estocolmo, 4-11-1938. Fototeca de Información Artística, Donación de Guadalupe Fernández Gascón. Instituto del Patrimonio Cultural Español (IPCE), Ministerio de Cultura.
} 
Buen conocedor de la arquitectura racionalista y del Movimiento Moderno, este profesor de la Escuela de Arquitectura de Madrid había destacado por sus proyectos urbanísticos para pueblos y por sus construcciones de bajo presupuesto. Entre sus obras más señaladas cabe citar el proyecto de un nuevo edificio para el Centro de Estudios Históricos en Madrid, que realizó precisamente junto con Sánchez Arcas. A comienzos de la Guerra Civil colaboró con José Lino Vaamonde, como Delegado y Consejero de la DGBA, construyendo y adaptando edificios para la salvaguarda del tesoro artístico ${ }^{15}$. Además, en plena guerra, asistió junto con Luis Lacasa -arquitecto que firmó con Josep Lluís Sert el Pabellón de París- al Congreso Internacional de la Vivienda que se celebró en Moscú en $1937^{16}$. No es casual, por lo tanto, que apareciese nombrado arquitecto del Pabellón español de la Exposición de Nueva York de 1939.

Apenas un mes después de la resolución, y gracias al buen resultado que se había obtenido con la experiencia parisina, el Ministerio de Presidencia del Consejo creó el 14 de noviembre de 1938 un Comité Interministerial de Dirección de la Participación Española en la Exposición Universal de Nueva York, con Sánchez Arcas como Presidente y Alfredo Bauer como secretario. La composición por los vocales de los distintos ministerios era la siguiente: Gonzalo Diéguez, Jefe de la Sección de América, por el de Estado; Laureano Sánchez Gallego, Director General de los Registros, por el de Justicia; Luis Lecuoma, por el de Defensa Nacional; Alcázar Huertas, Director General de lo Contencioso del Estado, por el de Hacienda y Economía; José Ignacio de Alberti y Gómez, Jefe de la Sección de Orden Público, por el de Gobernación; Francesc Galí, Director General de Bellas Artes, por el de Instrucción Pública; Antonio Gómez Zapatero, por el de Obras Públicas; Máximo Meyer López, por el de Comunicaciones y Transportes; Juan Relinque Esparragosa, por el de Trabajo y Asistencia Social; y por último, José Luis de Loma y Oteyza, Ingeniero Agrónomo, por el de Agricultura ${ }^{17}$.

El 15 de diciembre de 1938, este organismo nombraba a Juan Larrea, entonces Secretario de la Junta de Relaciones Culturales en París, Delegado del Comité español para la Exposición Internacional de Nueva York, lo que certificó una semana más tarde desde París el embajador Fernando González Arnao ${ }^{18}$. En torno a esas mismas fechas se hicieron las gestiones necesarias para que el Gobierno de la República francesa permitiese que todo el material que se recabó para ser exhibido en Nueva York pudiese transitar por territorio francés en franquicia de aduana o en depósito franco ${ }^{19}$.

Finalmente, el 7 de enero de 1939, a propuesta del Comité Interministerial de Dirección de la Participación Española, presidido entonces por el secretario de Negrín, José Prat, la Presidencia del Consejo de Ministros designaba al artista Ángel Ferrant, miembro de la JDTAM, para que atendiese a la preparación de las obras y los materiales que se enviarían a la Exposición de Nueva York ${ }^{20}$. Ferrant tenía una amplia experiencia en la salvaguarda del patrimonio artístico español desde principios de 1937, e incluso había colaborado en la organización de la Exposición de

15 Renau, Josep: Arte en peligro. 1936-1939, Valencia, Ayuntamiento de Valencia, 1980, p. 83.

16 Según Francisco Agramunt, se le encargó proyectar el Pabellón español de París de 1937, pero el arquitecto prefirió quedarse en Madrid, donde diseñaba refugios. Agramunt LaCruz, Francisco: "Tras las huellas de Jesús Martí Martín, artista castellonense", CIMAL, n. ${ }^{\circ}$ 15, Valencia, 1982, p. 14.

17 Gaceta de la República, n. ${ }^{\circ} 326,22-11-1938$, p. 700.

18 Carta de Sánchez Arcas a González Arnao, Barcelona, 16-12-1938. Certificado de González Arnao en favor de Larrea, París, 22-12-1938. AGA, Sec. AAEE, 54/11073.

${ }^{19}$ Carta del Secretario General del Ministerio de Estado a Marcelino Pascua, Embajador de España en París, Barcelona, 17-12-1938. Carta de Pascua al Ministerio de Asuntos Exteriores francés, París, 22-12-1938. Carta de Pascua al Ministro de Estado, París, 22-12-1938. Carta de la Dirección de Asuntos Políticos y Comerciales del Ministerio de Asuntos Exteriores francés, al Embajador de España en París, 2-1-1939. Carta de Pascua al Ministro de Estado, París, 3-1-1939. AGA, Sec. AAEE, 54/11073.

${ }^{20}$ Gaceta de la República, n. ${ }^{\circ}$ 8, 8-1-1939, p. 106. 
París recogiendo obras a petición de la $\mathrm{DGBA}^{21}$. También había trabajado codo con codo con Fernández Balbuena, Presidente de la JDTAM entre el 1 de julio de 1937 y el 10 de enero de 1938, hasta sustituirlo en el cargo cuando éste pasó a ocupar el puesto de Delegado de Madrid de la DGBA ${ }^{22}$. Su trayectoria en la JDTAM continuó hasta el 6 de septiembre de 1938, en que Manuel Gómez-Moreno asumió la presidencia, relegando al artista madrileño a una labor de régimen interno como Auxiliar Técnico de la misma institución.

Por último, hay que nombrar a una figura fundamental en la gestación de este proyecto: Luis Quintanilla. Debido a desavenencias internas en el gobierno de Negrín, no ocupó un puesto oficial en la organización de la Feria hasta que, finalmente, fue nombrado Agregado Cultural de la Embajada española en Washington ${ }^{23}$. Quintanilla era en esos momentos uno de los artistas españoles más conocidos en Nueva York. Su amistad con figuras destacadas, como Ernest Hemingway, John Dos Passos y Robert Capa, y sus exposiciones en la galería Pierre Matisse y en el MoMA, lo habían convertido en un personaje de moda y en una importante voz a favor de la causa republicana durante los años de guerra. Además, había desempeñado distintos cargos para el gobierno español, desde labores en el frente hasta misiones de espionaje y gestiones diplomáticas.

Por ello es interesante analizar su propio testimonio cuando recordaba cómo surgió la participación en la Exposición de Nueva York, necesariamente fechado a partir del verano de 1938, una vez publicada la resolución oficial del Gobierno, esto es, siendo ya efectiva la reorganización ministerial de Negrín de abril de ese año:

Eso fue un encargo de carácter oficial. Sencillamente se reunió el Consejo de Ministros para deliberar sobre el pabellón de España en la exposición, a la que el Gobierno, dada la difícil situación que atravesaba nuestra guerra, concedía gran importancia y decidieron que me encargase de ellos.

[...] Me enteré de las discusiones en el seno del Consejo de Ministros a través de Álvarez del Vayo. Bernardo Giner, que era ministro de Telecomunicaciones, se opuso abiertamente a mi designación, alegando que yo no estaba preparado para hacerme cargo de una obra de esa envergadura. Después supimos que trataba de colocar a Roberto Fernández Balbuena, que además de pintor era arquitecto como él, y muy amigo suyo. Negrín se calló y Prieto replicó, “¡No veo por qué no está preparado! Si no se explica usted mejor, no me convence". La discusión la zanjó González Peña, que acababa de regresar de Nueva York y había leído lo que decían los periódicos de mi exposición y dijo, "Hoy por hoy, el único pintor español del que se habla en Nueva York es Quintanilla"24.

El fragmento resulta revelador: Quintanilla acababa de terminar los frescos para el Monumento a Pablo Iglesias, y se situaba en la línea de los socialistas del bando frentepopulista. El conflicto del que hablaba en el citado Consejo de Ministros reflejaba la división que existía en ese momento entre los negristas y los prietistas. Sabemos que el arquitecto Giner de los Ríos, Mi-

21 Véase Alix TruebA, J.: "El Pabellón Español en la Exposición Internacional de París, 1937”, en Pabellón Español. op. cit., 1987, pp. 51-52. Álvarez Lopera, José: “Ángel Ferrant en la Guerra Civil”, Anales de Historia del Arte, Volumen Extraordinario, Madrid, UCM, 2008, p. 539.

${ }^{22}$ Gaceta de la República, n. ${ }^{\circ} 192,11-7-1937$, p. 168. "Junta del Tesoro Artístico de Madrid. 3. a etapa, año 1938". Archivo del Museo del Prado, Fondo Jiménez Quesada, pp. 2-3. Citado por Álvarez Lopera, José: Ibid., p. 547.

23 Quintanilla, Luis: "Pasatiempo". La vida de un pintor (Memorias), (ed., estudio y notas de Esther LóPeZ SobradO), A Coruña, Edicios do Castro, 2004, p. 468.

${ }^{24}$ Quintanilla, Joaquín F.: Al final de la cabriola, Burgos, Gran Vía, 2005, pp. 241-242. También encontramos sus opiniones a este respecto en: QuinTANILLA, L.: op. cit., 2004, p. 465. 
nistro de Comunicaciones, Transportes y Obras Públicas, consiguió su objetivo con el nombramiento de Balbuena como Comisario del Pabellón. Sin embargo, Quintanilla también obtuvo su parte, apoyado por Julio Álvarez del Vayo, Ministro de Estado, Ramón González Peña, de Justicia, y dos exministros con peso en el partido: Indalecio Prieto y Julián Zugazagoitia. Finalmente, de una forma o de otra, se le ofreció intervenir en las negociaciones entre España y la organización de la Exposición, como recogió de la siguiente manera en sus memorias:

La Feria Universal que se celebraría en Nueva York levantaba ya sus pabellones y construían los internacionales. Uno de los directores me invitó a una comida deseando estuviese representada España; hasta entonces las gestiones tramitadas por la Embajada no tenían contestación. El Director sabía que yo iba a regresar a Barcelona, y, como si fuese de gran interés personal suyo, me dio planos y demás documentos encargándonos resolver el asunto con el Gobierno de la República antes de fin de septiembre ${ }^{25}$.

Así lo corrobora una carta de Jay Allen, periodista amigo del pintor cántabro, a Albin Johnson, en la que se transcribe un telegrama suyo: "Comunica Johnson acuerdo concurrir exposición aceptando pabellón número 7 grupo 1 stop Don Fernando informado. Luis" ${ }^{26}$.

La labor de Quintanilla no se limitó sólo a la organización de ciertos aspectos del Pabellón, sino que, como veremos, también fue uno de los artistas que trabajaron en sus contenidos, en concreto, al crear los frescos que hoy constituyen la única obra conservada que se proyectó específicamente para el evento neoyorquino.

\section{El Pabellón español de Nueva York. Continente y contenido}

La Exposición Internacional de Nueva York se configuró a partir del hilo conductor temático sobre el Mundo del Mañana. Tenía como centro neurálgico el monumento de la Perisphere y el Trylon -una gran esfera y un obelisco de tres caras- y a su alrededor se distribuyeron más de cuatrocientas hectáreas entre el Hall de las Naciones, el Patio de la Paz, la Laguna de las Naciones, el Lago de la Fuente y otros tantos bulevares, avenidas y plazas. Sumados a los pabellones particulares de más de un centenar de países, se construyeron edificios en torno a las comunicaciones, la alimentación, el servicio médico, la ciencia, la educación, los transportes, los inventos y el ocio $^{27}$. Para todo ello, se guardaron unas pautas de homogeneización estilística de las fachadas y alturas de los edificios, así como de la escultura dispuesta en los exteriores ${ }^{28}$. El Consejo de Diseño de la organización determinó que las estatuas y las luces exteriores de los edificios debían tener un efecto general armonioso con el conjunto de las construcciones e iluminar de forma difuminada. Los carteles identificativos tenían que colocarse en una parte significativa de la fachada, integrarse en el diseño arquitectónico, no estar colocados a una altura mayor de quince pies sobre el nivel del suelo, ni darle más relevancia de la que se permitía al conjunto de los pabellones ${ }^{29}$.

Poco sabemos todavía del aspecto que debía de tener el proyecto del Pabellón español. Hasta el momento no se han localizado planos ni alzados del espacio designado, y sólo podemos

\footnotetext{
25 Idem, p. 453.

${ }^{26}$ Carta de Allen a Johnson, Nueva York, 6-9-1938. NYWF 1939-1940. C. 1503, carp. 1. NYPL.

27 Perley Boone: Nota de prensa de la Exposición Internacional de Nueva York, traducida al castellano. Nueva York, Inc. Department of Press, s.f. NYWF 1939-1940. C. 319, carp. 2. NYPL.

28 Véase FABRA: "La Exposición Internacional de Nueva York de 1939”, La Vanguardia, Barcelona, 28-8-1938, p. 3.

${ }^{29}$ Carta de Roosevelt a De los Ríos, Nueva York, 20-2-1939. NYWF 1939-1940. C. 319, carp. 2. NYPL.
} 
servirnos de los datos que se pueden extraer de las cartas que acompañaban a esos documentos y que, en muchas ocasiones, se trata de propuestas provisionales, y no de las resoluciones definitivas con que se podían haber encontrado los arquitectos en el proceso de construcción del edificio.

Antes de pasar a detallar los datos documentales recogidos en esta investigación, es conveniente tener en mente el tipo de arquitectura moderna que se estaba proyectando en España a principios de la década de los treinta. El Pabellón de Nueva York debió de estar concebido de manera muy similar al tipo de construcción que se había llevado a París un año antes, pues no sólo coinciden ambos pabellones en la función y en el tiempo, sino que también sus autores, Sert, Lacasa y Martí, compartieron influencias y formación; los dos primeros, en el contexto del GATEPAC catalán y el tercero, en la Generación del 25 madrileña.

Hemos podido determinar que el espacio designado a España, en el Hall of Nations, fue el denominado GQ-7, originalmente ocupado por Suecia (fig. 1) ${ }^{30}$. El objetivo de esta sección de la Exposición era mostrar siete grupos de edificios adosados, cada uno de los cuales estaba dividido en espacios de exhibición separados, con entradas individuales coronadas por esculturas simbólicas que representaran a las naciones participantes. El edificio de los Estados Unidos dominaba el Court of Peace, dando la impresión de una unidad mundial bajo su presidencia ${ }^{31}$. El edificio asignado a España era uno de los cinco espacios del conjunto GQ, el lado oriental de la Lagoon of Nations, que compartía con Lituania, Irak, Japón y la URSS (fig. 2) ) $^{32}$ Tenía forma ligeramente trapezoidal, con acceso de entrada por las dos fachadas. Se estructuraba gracias a un armazón de hierro, y a vigas y soportes de madera que distribuían longitudinalmente el espacio en dos mitades de seis particiones cada una. Se dividía en dos plantas: un piso bajo y un entresuelo con estructura de hierro, que se solicitó añadir a la obra básica ofrecida por la organización $^{33}$ y que se sostenía por medio de colgadores enganchados a las vigas de madera de la cubierta $^{34}$. Las paredes estaban revocadas con media pulgada de yeso, el suelo se dejó con un

${ }^{30}$ Carta de Standley a Wharton Green, Nueva York, 9-9-1938. NYWF 1939-1940. C. 1503, carp. 1. NYPL.

31 Zim, Larry; Lerner, Mel; Rolfes, Herbert: The World of Tomorrow. The 1939 New York World's Fair, Nueva York, Harper \& Row, 1988, pp. 150-151.

32 WuRTs, Richard (et al.): The New York World's Fair 1939/1940, Nueva York, Dover, 1977.

33 Algunos extractos de la documentación detallan la siguiente información: "The Spanish Government is desirous of obtaining additional space in the form of a mezzanine floor for their exhibition, and we will furnish you, on or before the first of October, the necessary plans to facilitate construction of this space" (Carta de Pomerance a Standley, Nueva York, 23-9-1938). "Herewith are two blueprints of our Sketch ST-115-Q7 showing proposed framing for mezzanine floor in GQ-7. With the proposed location of hangers, maximum depth of beam will be $18^{\prime \prime}$ which will allow for a construction depth of approximately 20 to 21 ". Between Columns 77 and 88 is shown only one rod hanger approximately in the center of the span. If it is desirable this can be changed to two hangers in order to keep the center portion of this mezzanine area clear from obstructions" (Carta de P.A. Strobel a I.L.Scott, Nueva York, 20-10-1938). "The Spanish architect has shown mezzanine supported on posts from first floor construction. We have indicated a total of four hangers from the roof construction, two of which are completely concealed in stair partitions. The other two hangers marked «H3» and «H4» are so located that they do not interfere with circumferential traffic and exhibit space at center of mezzanine" (Carta de Strobel a Scott, Nueva York, 15-11-1938). "I am sending you enclosed two copies of our drawing I-GQ-7-ST-204 showing the detail of the mezzanine floor framing. Those items the cost of which are to be borne by the participant are designated by the letter «P»" (Carta del Ingeniero de la Exposición a Pomerance \& Breines, Nueva York, 29-12-1938). NYWF 1939-1940. C. 1503, carp. 1. NYPL.

34 "We have indicated on the sketch referred to, the proposed framing for the mezzanine floor in this section. We also show suggested location of hangers which will allow maximum depth of floor construction of 20 to 21 inches. The depth of the beam will be 13 . Between columns \#77 and \#88, we indicate only one red hanger approximately in the center of the span. If the participant so desires, this can be replaced by two hangers in order to keep the center portion of his mezzanine free from obstructions" (Carta de Green a Pomerance \& Breines, Nueva York, 26-10-1938). "The Fair Corporation will allow a credit for the application and furnishing of wallboard on all exterior walls, the under side of the mezzanine 


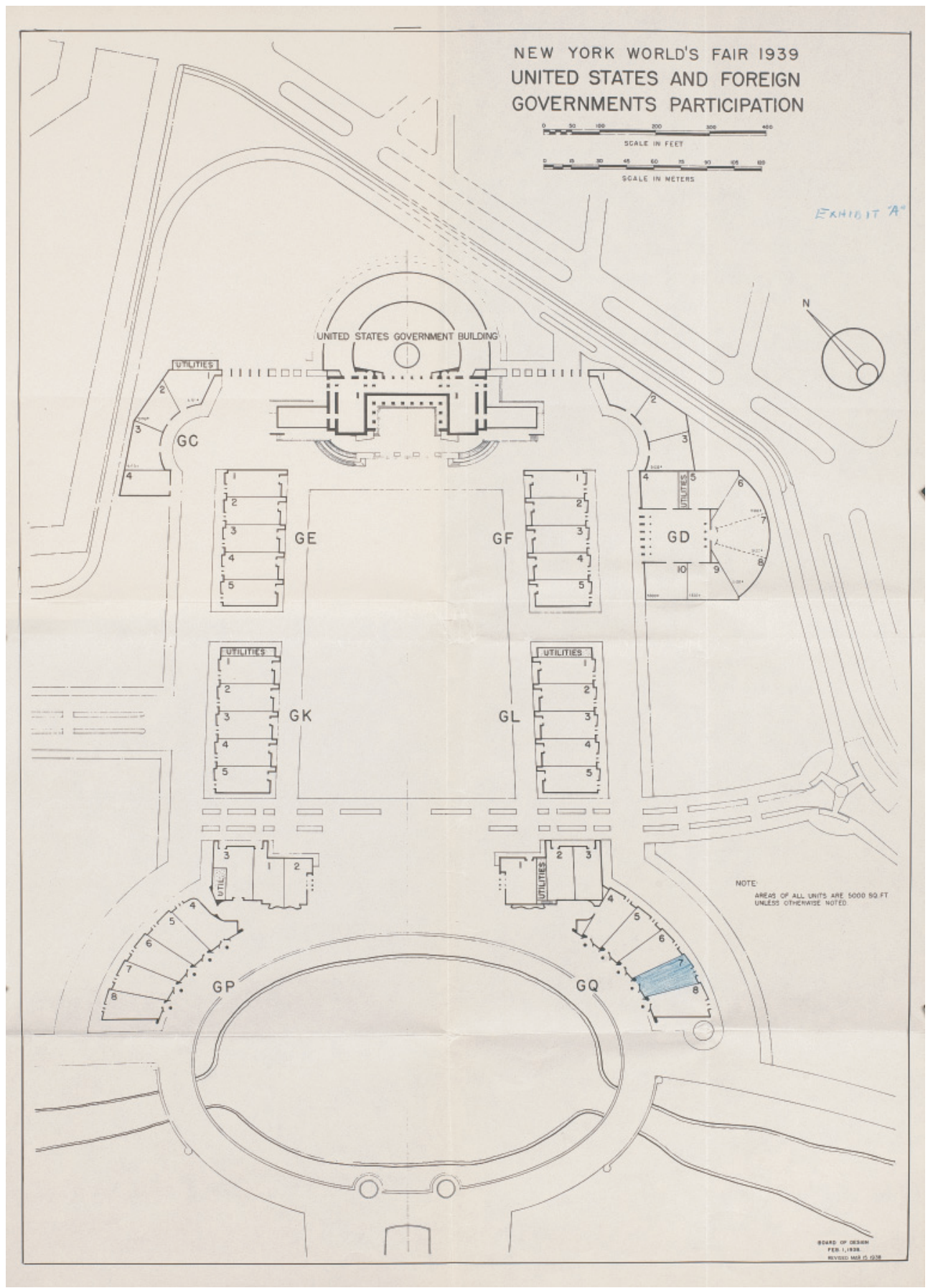

Fig. 1. Plano con el espacio designado al Pabellón español en el contrato entre el Gobierno de la República española y la New York World's Fair, Nueva York, 9-9-1938. New York World's Fair 1939-1940 Records, Manuscripts and Archives Division, The New York Public Library, Astor, Lenox and Tilden Foundations. 
acabado tosco y la fachada se recubrió con un estuco de cemento ${ }^{35}$, para que los comisarios españoles diseñaran el resto del edificio y su discurso expositivo ${ }^{36}$. La construcción interior del Pabellón debía estar finalizada para el 15 de enero de 1939, y la instalación de la exposición, para el 30 de marzo de ese año, con vistas a inaugurarlo a primeros del mes de abril ${ }^{37}$.

Como adelantábamos anteriormente, respecto a su contenido, el Pabellón español de la Exposición Internacional de Nueva York tomó como modelo la experiencia parisina. Para ello, se planificó de nuevo una muestra orientada a la propaganda republicana a través de la tradición y la vanguardia de su cultura. En la información preeliminar enviada desde la Embajada en Washington se insistía en ello:

Efforts will be made to show visitors from all nations Spain's geography, landscape, natural resources, village life - of such varied racial characteristics - customs handed down from days of old, as well as Spain's spiritual achievements, both in the traditional folklore form preserved by the people and in scientific, artistic and literary manifestations. [...] Our greatest artists will show the continuity of Spanish tradition and intellectual values. It will be shown that in the midst of the struggle art rises in the battlefields. An eloquent characteristic of the Spanish War is that a rich production of poetic and pictorial works have sprung in the very tranches, where the enemies of Spain and of European culture sow death.

Painting, sculpture, drawings, literature, folk art, and music of different periods up to the present will have their place in the Spanish pavilion, together with samples of Spanish industry and natural wealth. [...]

These are difficult times for Spain, but she will respond to the invitation to take part in the New York World's Fair by presenting a synthesis of what our nation was in the past, what it is now, and of the guiding ideals in building the new Spain of the future ${ }^{38}$.

ceiling, and the ceiling over the entire space. In the case of ceiling over the entire space, allowance is also given for the hangers and furring members necessary to bring the ceiling to the required levels. A credit will also be allowed for the erection of a 2 x 6 partition dividing the Spanish Space from Spaces Z-6 and Z-8. This stud work is to be erected 6-1/4" from center line of column to rough face of studs. [...] The Fair will furnish and erect without cost to the Spanish Government the mezzanine steel, the wood joists and rough floor, and the standard steel staircases and supports under stair strings" (Carta de Roosevelt a De los Ríos, Nueva York, 27-1-1939). NYWF 1939-1940. C. 319, carp. 2. NYPL.

35 "The building will be constructed with a steel frame and wooden studs and joists. The Fair Corporation will finish the walls and ceiling with one-half inch plaster board which will be left unpainted. Rough floors will be installed. The mezzanine floor will be furnished by the Fair Corporation in accordance with designs of the participant but such designs must be received not later than September 15, 1938. It will be provided with a rough floor and stairs for access of steel construction with cement treads. The exterior of the building will be of cement stucco". Carta de Green a la Oficina del Comercial Adjunto de la Embajada Española en Washington (Ignacio García del Castillo), Nueva York, 16-9-938. NYWF 1939-1940. C. 1503, carp. 1. NYPL.

36 "The free covered space will be furnished to your Government with rough, unfinished walls and ceilings and your Government should, at its own expense, complete the space for occupancy, including the finishing of the floors, walls and ceiling and such interior and exterior decoration, fixtures and architectural characteristics as you may be desired". Carta de Standley a García del Castillo, Nueva York, 31-3-1938. NYWF 1939-1940. C. 1503, carp. 1. NYPL.

37 Carta de Green a Pomerance \& Breines, Nueva York, 18-11-1938. NYWF 1939-1940. C. 1503, carp. 1. NYPL.

${ }^{38}$ El texto continuaba diciendo: "Sculpture, architecture, painting and music will be featured at the Fair as far as present conditions allow. [...] Original and ancient documents of great intrinsic and historical value, jealously protected by the government with the help, enthusiasm and respect of the Spanish people during the difficult foreign invasion visited upon Spain, will be shown, together with additions unknown until now to Scholars. By means of these tangible evidences of Spanish history, the past will speak to World's Fair visitors through its most universal figures. The present will do so through the deeds of its outstanding men". Preliminary Information about Spain's participation in the New York World's Fair of 1939, Washington, D.C., 22-12-1938. NYWF 1939-1940. C. 319, carp. 2. NYPL. 


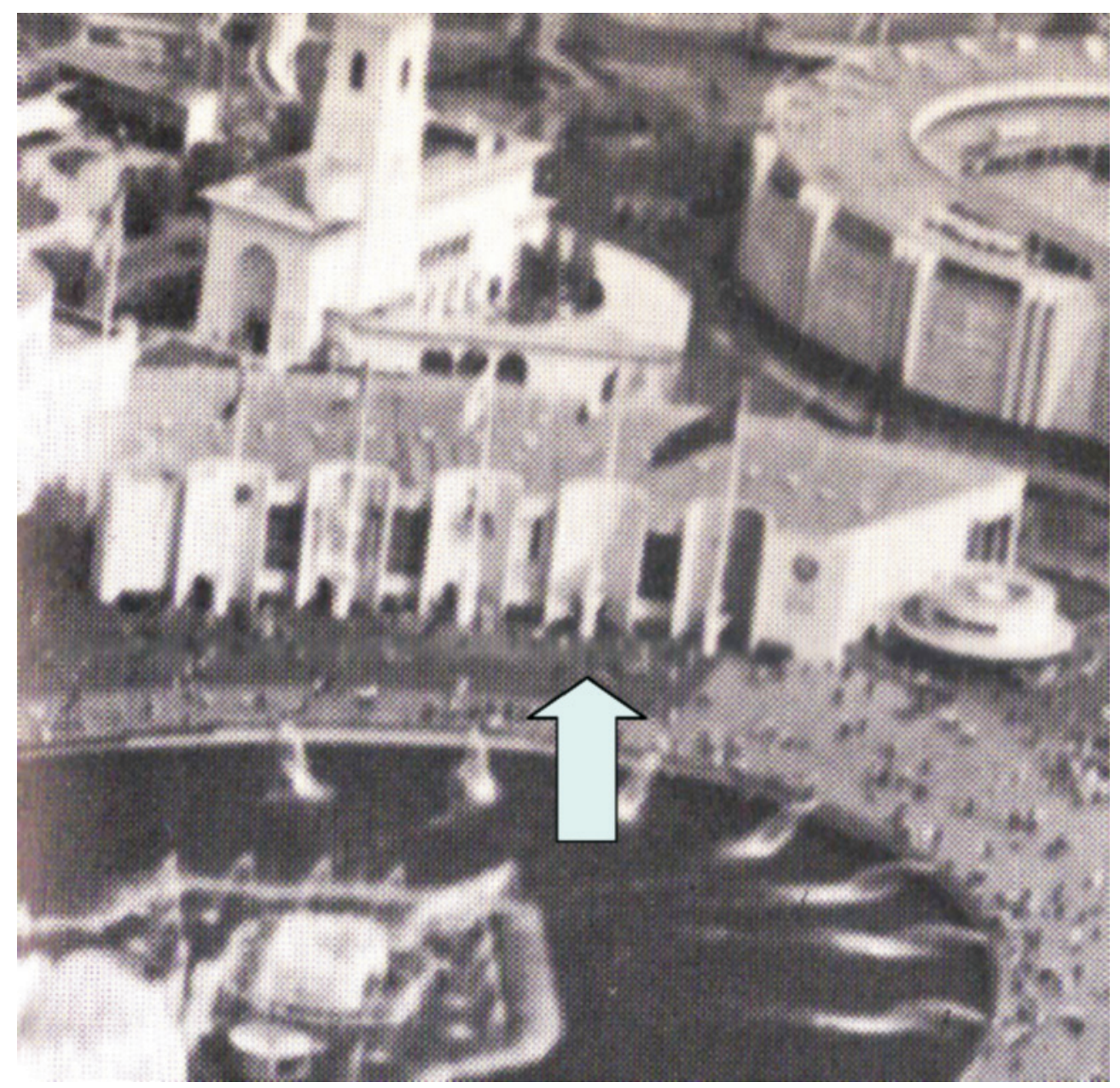

Fig. 2. Detalle de fotografía aérea en la que se aprecian los edificios GQ, entre ellos, está señalado el espacio destinado al Pabellón español.

Por lo tanto, los objetivos se resumían en la presentación de las características culturales y naturales más sobresalientes de España, con una especial atención a las artes, las ciencias, la herencia cultural colonizadora española, y la presentación de materiales históricos originales junto a las obras de poetas, artistas e intelectuales contemporáneos del país en guerra. "It will be, in short, an exposition of a country in war" 39 . Sin embargo, esta visión tuvo opositores, más por la orientación política de sus organizadores que por tratarse de unos objetivos poco ambiciosos. Así, opiniones como la de Quintanilla ejemplifican de nuevo estas tensiones internas dentro de la organización republicana a las que ya nos hemos referido, y que en 1938 habían dado lugar a la crisis ministerial del gobierno de Negrín:

El proyecto de acudir a la Feria Universal de Nueva York lo aprobó el Gobierno. Los americanos nos cedían un pabellón gratuitamente y sólo debíamos decorarlo, siendo ellos los

39 “Spanish Loyalists Plan Fair Exhibit”, op. cit., 1-9-1938, p. 23. 
proponentes de que realizase yo ese trabajo artístico. También el grupo comunista dirigía la sección de propaganda encargada de preparar lo necesario para la exposición, y se orientó por el manoseado tema de lo popular, el ya universalmente conocido "folklore" español: como ocupaban esos puestos algunos seudointelectuales del momento, varios arquitectos de origen burgués y los poetas de última hornada que he hablado, su imaginación no dio más de sí. Pero obedecían a las consignas ordenadas por seres misteriosos, y no siendo yo gallina de su corral, hipócritamente a la manera jesuita (recordaré que más de un intelectual ruso comparaba a San Ignacio de Loyola con Lenin), me hacían perder el tiempo ${ }^{40}$.

Efectivamente, Quintanilla, a pesar de no comulgar con esa perspectiva del arte y la propaganda en la que insistió el giro gubernamental hacia los comunistas, desempeñó un lugar importante tanto en la organización de la parte expositiva del Pabellón como en la propia realización de las obras. En cuanto a la función organizativa, podemos recuperar un fragmento de sus $\mathrm{Me}$ morias en el que recordaba cómo contactó con Joan Rebull y Joaquim Sunyer para que colaborasen en la muestra:

Cansado de superar las demoras de mala voluntad del grupo comunista ocupado de organizar la exposición de Nueva York, le conté los detalles a Zugazagoitia, que por nuestra entrañable amistad, como él describió en mi libro de los dibujos de la Cárcel, era mi coincidente, y Zugazagoitia se limitó a decirme: "Acuérdate de cuando eras el jefe del Cuartel de la Montaña"; sus palabras me bastaron para saber lo que debía hacer. Activé concediese el presupuesto el Ministerio de Hacienda; yo mismo busqué mis colaboradores, el escultor Juan Rebull y el pintor Joaquín Suyner [sic]; a uno y otro les preparé el medio de realizar su trabajo en Francia; a Rebull le llevé a la frontera, y habilité un local en Barcelona donde se fuesen depositando las mercancías que se irían a exponer. El grupo comunista me seguía a empujones, y cuando titubeaba o intentaba discutir, le repetía "órdenes de Moscú", broma que les sentaba mal, pero callaban ${ }^{41}$.

Parece que Zugazagoitia - que además de haber ocupado la cartera de Gobernación hasta abril del 38, había sido interino de Hacienda y Economía durante la ausencia de Negrín-, tenía cierto contacto con el titular de esa cartera, Francisco Méndez, pues era de ella de quien dependía la financiación del Pabellón. Por otro lado, la información que aportaba Quintanilla sobre Sunyer era corroborada por el New York Times, quizás proporcionada por el mismo artista. En la siguiente noticia se precisó incluso qué tipo de obras enviaría cada uno:

Luis Quintanilla will paint four fresco panels for the walls, one of them dealing with the Lincoln-Washington Battalion of the International Brigade. Joaquin Suner [sic], at present in Paris, will have a large canvas ${ }^{42}$.

En realidad, el encargo consistió en cinco paneles de fresco (cuatro de ellos de $2 \times 2,5 \mathrm{~m}$. y el quinto, de $2 \times 1,5$ m.), titulados Hunger, Flight, Destruction, Pain y Soldiers, englobados bajo el lema "The Actual Moment in Spain"43. El propio Quintanilla habló de esta temática al

40 QuinTANILLA, L.: op. cit., 2004, pp. 465.

${ }^{41}$ Quintanilla, L.: Ibid., 2004, pp. 465-466.

42 "Spanish Loyalists Plan Fair Exhibit”, op. cit., 1-9-1938, p. 23.

${ }^{43}$ Más tarde se conoció el conjunto con el título “Ama la paz y odia la guerra”. La participación de Quintanilla ha sido profundamente investigada por Esther López Sobrado y Javier Gómez Martínez, por lo que remitimos a sus estudios para cuestiones más concretas. Véanse: Los frescos de Luis Quintanilla sobre la Guerra [cat. exp.], Santander, Universidad de Cantabria, 2007. LóPEz SOBRADO, Esther: "La Guerra Civil a través de la mirada de Luis Quintanilla", Congreso Internacional La Guerra Civil Española, Madrid, SECC, 2007. GóMEz MARTínez, Javier: "Los frescos de 
citar su obra en una carta abierta a su amigo Hemingway ${ }^{44}$. Aunque los frescos no pudieron llegar a exhibirse, sí fue la única obra terminada para la Exposición de Estados Unidos, así que Quintanilla aprovechó para exponerla en la muestra que se le dedicó en la sede de la Associated American Artists. La crítica Elizabeth McCausland recogió una acertada interpretación de cada panel: en Hunger, las mujeres y los niños mueren de hambre a causa del bloqueo forzado por las naciones "neutrales"; Flight refleja la huida del pueblo orgulloso que, a pesar de ser destruido, no se deja conquistar; Destruction afirma que es mejor morir de pie que vivir de rodillas; y por último, dos homenajes: Soldiers, a los americanos que combatieron en el Batallón Lincoln, y Pain, a las enfermeras de la Cruz Roja ${ }^{45}$. Entre ellos, el dedicado a los soldados constituye una verdadera galería de retratos. Aunque sólo se ha conseguido identificar en él a José Bergamín y a Herbert Mattews, probablemente el resto de personajes estén relacionados con la Brigada Lincoln en España, aunque no hemos sido capaces de corroborarlo ${ }^{46}$. En cualquier caso, queda clara la intención de Quintanilla de homenajear la iniciativa estadounidense que, obviando la línea oficial de no intervención, apoyó la causa española republicana a través de las Brigadas Internacionales.

Desconocemos el orden de los paneles, aunque sabemos que su ubicación iba a ser el interior del Pabellón. En un pequeño croquis fechado el 28 de abril de 1939, conservado entre la documentación neoyorquina, se puede leer "Spanish Murals. A. Johnson", acompañando a los cinco recuadros que aluden claramente a los paneles del artista cántabro (fig. 3). En el centro está colocado el de dimensiones diferentes, Hunger, mientras que los demás lo acompañan en una disposición continua, a la manera de un políptico, por lo que podemos deducir que se colgarían de un mismo muro ${ }^{47}$. Sobre su distribución, aunque ya existen algunas hipótesis, tras una comparación entre los esquemas descubiertos y las fuentes críticas conservadas, podemos sugerir una nueva interpretación que quizás pueda enriquecer el debate (fig. 4). Ésta dejaría a los lados Soldiers y Pain, los marcos del homenaje, mientras que a derecha e izquierda de Hunger irían, respectivamente, Flight y Destruction, formando entre los tres el tríptico de las consecuencias de la guerra.

El segundo de los artistas implicados, citados en el mencionado periódico americano, fue Joaquim Sunyer. El catalán, exiliado ya en Francia desde los primeros momentos de la guerra, era un gran amigo de Quintanilla. De su participación la prensa aseguró que consistiría en un gran óleo, aunque desconocemos más detalles. Sólo tenemos noticia de que en la fachada trasera del Pabellón se iba a mostrar un mural que representase el Erika Reed, el primer barco americano que llevó comida y medicamentos a España durante la Guerra Civil y que, por mediación de la Brigada Lincoln, ayudó a evacuar a algunos españoles ${ }^{48}$. La producción que nos ha llegado de Sunyer durante los años de guerra y el primer exilio continúa la línea que desarrolló en su juventud como uno de los emblemas del Noucentisme. Su estilo clasicista y su gusto mediterraneísta

Quintanilla en Nueva York, hoy instalados en Santander", en Lorente, Jesús Pedro; SÁnchez Giménez, Sofía; y CABañas Bravo, Miguel: Vae victis! Los artistas del exilio y sus museos, Gijón, Trea, 2009, pp. 215-229.

44 "The frescoes have no bitterness, I think, just as they have not the grandiloquence of the bellicose spirit. They are humble and if in them there is ideological sin, it is in the moralistic ingenuousness of saying: love peace and hate war. Painting them soothed my pain [...]". Quintanilla, Luis: “An Open Letter to Ernest Hemingway", en QuinTANILLA, Paul: Waiting at the Shore, Lulu Press, s.f. http://www.lqart.org/textfold/excerpts.html [Consulta: $16 / 10 / 2009]$.

45 McCausland, Elizabeth: "Exhibitions in New York", Parnassus, vol. 11, n. ${ }^{\circ}$ 7, College Art Association, Nueva York, noviembre de 1939, p. 16.

${ }^{46}$ López Sobrado, E.: “Ama la paz y odia la guerra. Los frescos de Luis Quintanilla sobre la Guerra Civil”, en Los frescos de Luis Quintanilla..., op. cit., 2007, p. 28.

47 "Spanish Murals". NYWF 1939-1940. C. 319, carp. 2. NYPL.

48 Official Guide Book of the New York World's Fair, Nueva York, Exposition Publications, 1939, p. 146. 


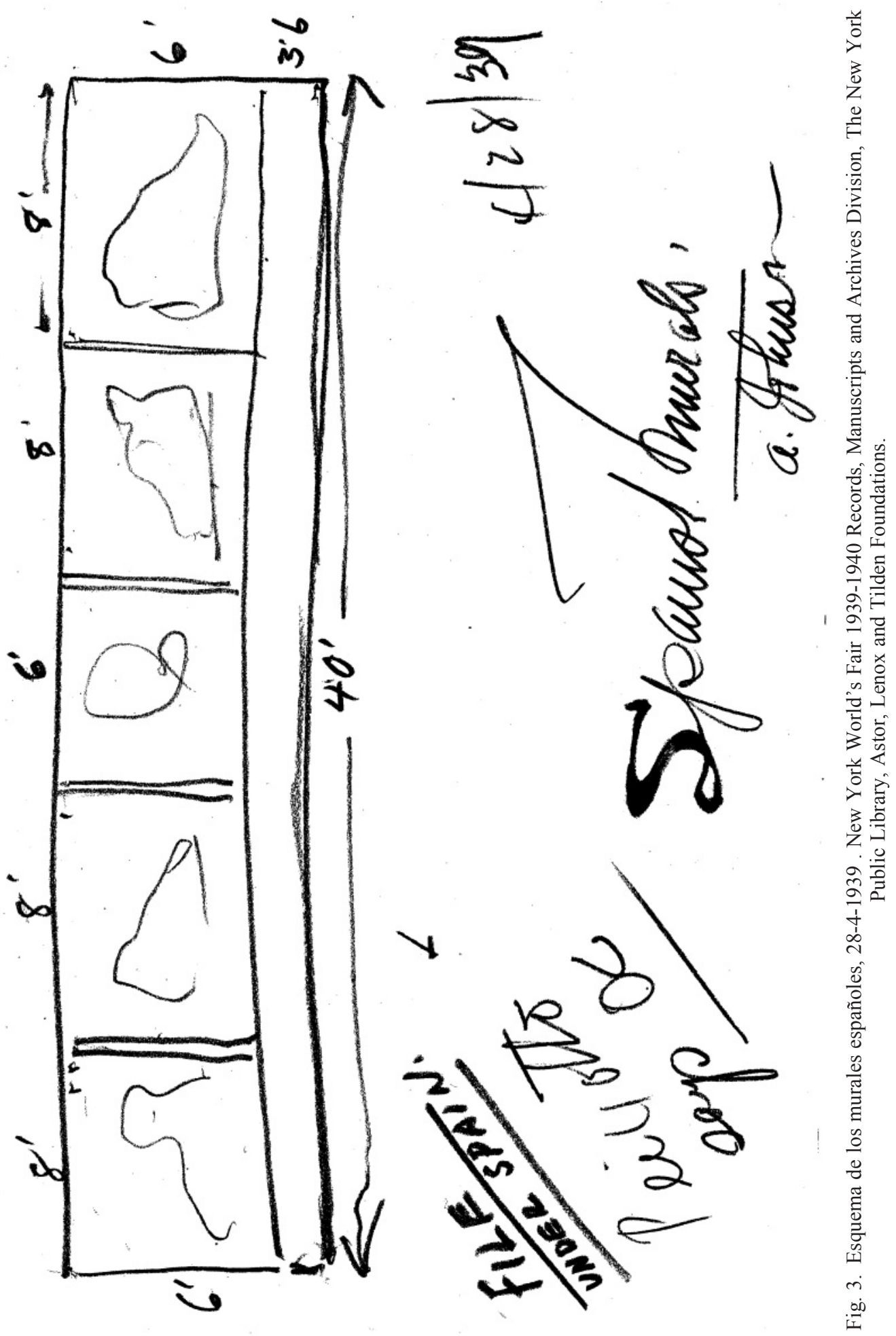




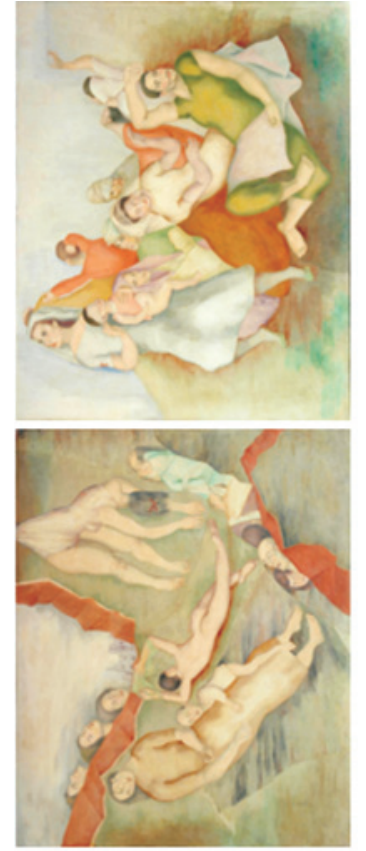

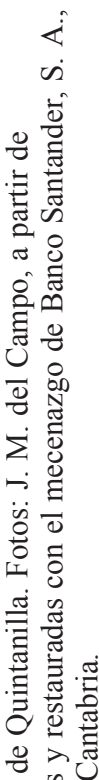

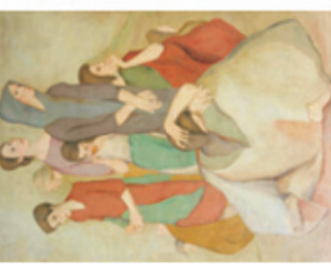

제용

焉要

政

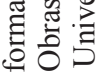

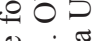

चु०े

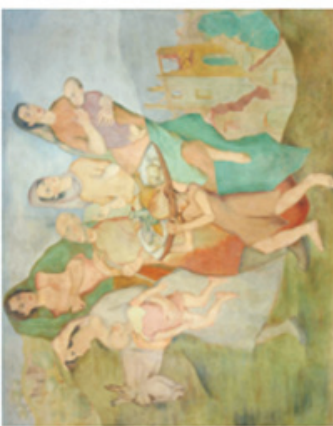

离

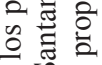

in

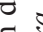

$\frac{0}{0} \frac{0}{5}$

象

일

․․

ํํㄴ

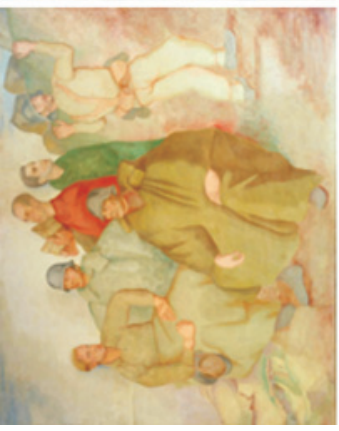

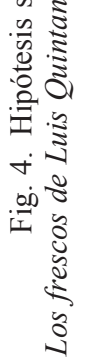

AEA, LXXXIII, 331, JULIO-SEPTIEMBRE 2010, 213-234, ISSN: 0004-0428 
concuerdan a la perfección con la presencia de la figuración y los realismos, a grosso modo, de la pintura que se exhibió en Nueva York durante la Feria.

Por su parte, el otro artista que mencionaba Quintanilla fue Joan Rebull, quien había pasado los años de la II República no sólo llevando a cabo una intensa actividad artística, sino que también se introdujo en la gestión, al integrarse en la Junta de Museus, y en la docencia, a través de la fundación de una escuela de arte. Durante los años de guerra fue comisario del patrimonio artístico de Tarragona, aunque no descuidó su labor creativa -de hecho participó en distintas exposiciones colectivas sobre arte y compromiso, en las que se le concedieron varios premios, entre ellos, el Nacional de Escultura ${ }^{49}$. Como hemos señalado, por iniciativa de Quintanilla, se le ofreció realizar una escultura para el frontispicio del Pabellón ${ }^{50}$, para lo que el artista cántabro le llevó hasta la frontera de los Pirineos y le facilitó un estudio en París que probablemente compartió con Sunyer, del que era amigo. Sabemos que las estatuas pensadas para formar parte de la Parade Ground de la Exposición, integradas en las fachadas de los pabellones extranjeros, debían tener una altura uniforme de doce pies, y estar fabricadas preferentemente con yeso, aunque parece que la de Rebull era una escultura de caoba ${ }^{51}$. Gracias a las fotografías de los distintos pabellones del Hall of Nations podemos encontrar similitudes estilísticas entre las figuras rotundas de los nuevos realismos. En este sentido, la línea de Rebull era idónea para la fachada del Pabellón de España.

Pero no sólo sabemos de estas participaciones, gracias a los testimonios de Quintanilla, pues también Josep Renau, Director General de Bellas Artes hasta abril de 1938, preveía intervenir en el Pabellón -como hiciera en París- por medio de una serie de fotomontajes:

El periodo más bajo de mi productividad artística fue, precisamente, el de mi gestión como Director General de Bellas Artes. Los carteles y fotomontajes de esta etapa fueron realizados generalmente los fines de semana y robando tiempo al sueño. Sólo la parte gráfica del pabellón de España en la Exposición Internacional de París, 1937, y los grandes fotomontajes sobre los llamados "13 Puntos de Negrín" (destinados a la Feria Internacional de New York, 1939) fueron hechos dentro del tiempo de mi cargo ${ }^{52}$.

No obstante, sabemos que existen algunas imprecisiones en este testimonio. Renau dimitió de la DGBA el 22 de abril de 1938, y los 13 puntos de Negrín no se hicieron públicos hasta el día 30. Sí que es cierto que muchos de los elementos de estos grandes fotomontajes, como las escenas agrarias, las figuras militares y los atletas, habían aparecido ya en otros que formaron parte del programa cartelístico rotativo del 37 en París, y que Renau había recuperado de su archivo fotográfico. Por ello es posible interpretar que algunas de esas imágenes se fueron configurando a lo largo de esos años y, finalmente, se orientaron hacia el Pabellón de Nueva York. Además, algunos de los ejemplares que se han conservado presentan grabado el escudo de la República, lo que, además de otorgar un carácter oficial a la imagen, quizás puedan aludir al fin propagandístico de la tirada, probablemente destinada a la Feria (fig. 5).

En último lugar, citamos la obra que, debido al impacto que causó en París, fue reutilizada en el proyecto de Nueva York: la Fuente de Mercurio de Calder. Esta escultura, que ponía de

49 Véase Joan Rebull. Años 20 y 30 [cat. exp.], Madrid, MNCARS, 2004, pp. 156-158.

50 Selva I Vives, Josep: L'escultor Joan Rebull, Reus, Asociación de Estudios Reusenses, p. 38.

51 Carta de Voorhers, Jefe del Consejo de Diseño, al Jefe de Ingenieros y Director de Construcción, Nueva York, 6-10-1938. Carta de Roosevelt a De los Ríos, Nueva York, 23-1-1939. NYWF 1939-1940. C. 319, carp. 2. NYPL. Official Guide Book..., op. cit., 1939, p. 146.

52 ReNAU, Josep: op. cit., 1980, p. 15. 


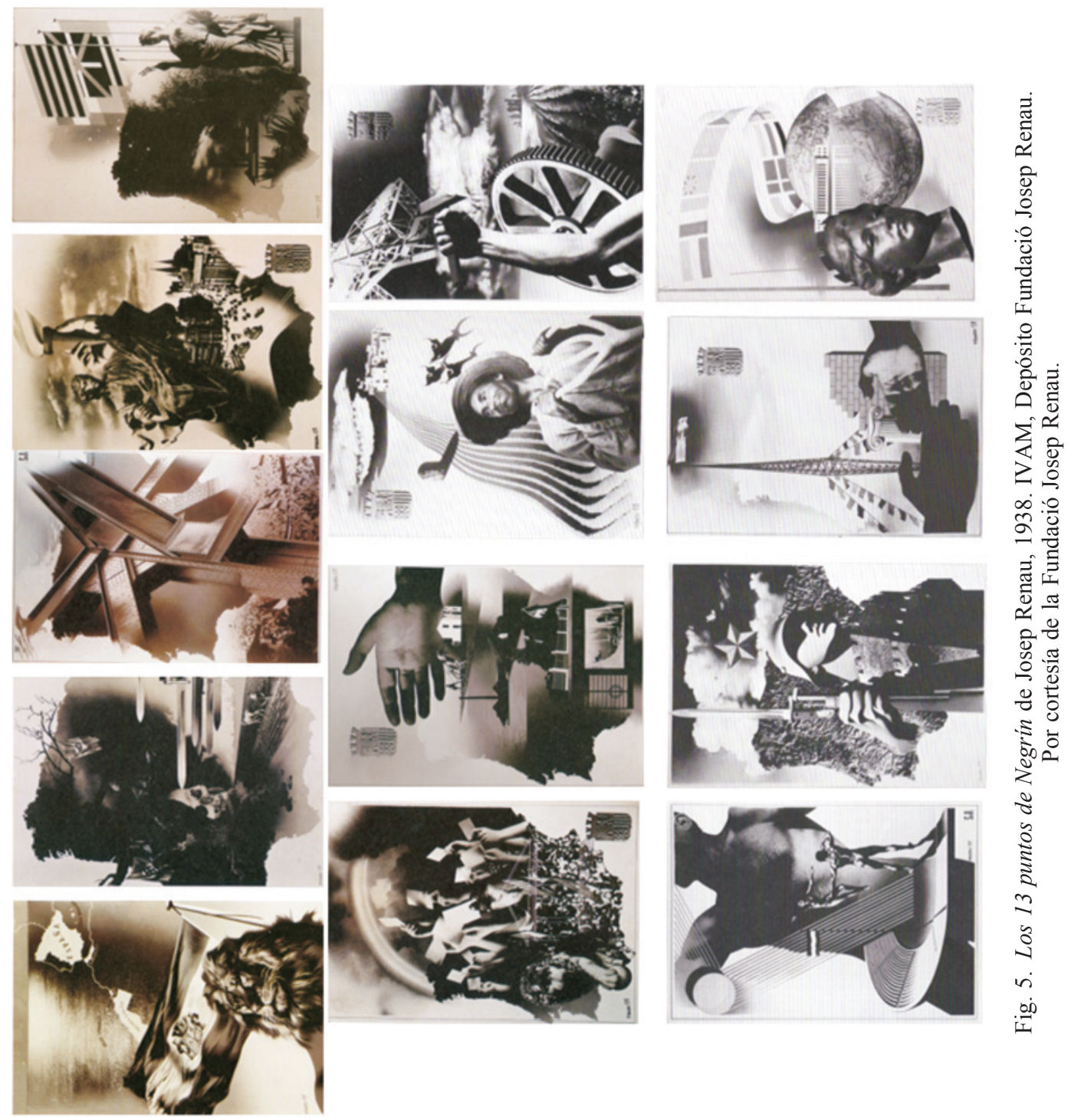


manifiesto la importancia de las minas de Almadén - uno de los objetivos del bando franquista y también un icono de la riqueza natural española-, había llamado la atención del público y de la crítica. Además, la colaboración de un artista norteamericano tan reputado como Calder también pudo servir de respaldo a la causa republicana en la Exposición estadounidense, quizás la razón por la que ocupó un lugar preferente en los planos del nuevo proyecto. Debido a sus grandes dimensiones, fue necesario un refuerzo en los cimientos del edificio y, de hecho, se recomendó colocar un pedestal mayor que permitiese esconder los sistemas de circulación del mercurio sin tener que excavar por debajo ${ }^{53}$.

No sabemos con exactitud qué otras obras estaban pensadas para ser albergadas en el Pabellón español durante la Exposición. Sólo podemos suponer que, al igual que sucedió con la Fuente de Calder, quizás hubiese otras obras del Pabellón de París que también se quisieron exponer en Nueva York. Uno de los pocos ámbitos de la Exposición de 1937 que todavía no está muy aclarado es el de la devolución de las obras a España. Hay que recordar que el 25 de febrero de 1938 una parte de los materiales expuestos ya se habían mandado de vuelta, aunque otros tantos -las dependientes del País Vasco y Cataluña, y las colecciones de artesanía y folklore depositadas en el Trocadero- permanecían en la capital francesa. De hecho, se conserva una carta de Juan Larrea, Delegado del Comité español, enviada al Director del Musée de l'Homme de París, fechada en diciembre de 1938, en la que solicitaba que se pusiesen a su disposición cuatro cajas que contenían los trajes que habían sido expuestos en el Pabellón parisino, quizás con intención de mandarlos a Nueva York ${ }^{54}$.

Por otro lado, desconocemos la participación de otros artistas contemporáneos además de los mencionados. Sólo podemos apuntar los viajes a Nueva York de Alfonso Rodríguez Castelao en julio de 1938, con el encargo de Negrín de realizar labores de propaganda, así como el de Gabriel García Maroto en las mismas fechas, enviado por Álvarez del Vayo. Todavía no estaba aprobada la participación oficial de España en la Feria, aunque cabe preguntarse si quizás parte de esa producción -como el álbum de estampas Milicianos de Maroto, publicada entonces en Nueva York- se podría haber pensado, antes o después, como parte de los materiales expuestos en el Pabellón. Además, señalaremos la continuidad de un sistema que se había aplicado a la muestra de París, en el cual la DGBA convocaba diferentes Concursos trimestrales en los que adquiría las obras premiadas para luego exponerlas de forma oficial. Es posible pensar que el destino de algunas de estas piezas elegidas en 1938 pudiese haber resultado la exhibición de Nueva York ${ }^{55}$.

Finalmente, debemos señalar aquí la presencia del arte español expuesto al margen del proyecto republicano. En primer lugar, destacamos la pintura española que formó parte de la muestra Masterpieces of Art. European Paintings and Sculpture from 1300-1800, organizada por Art

53 "We propose to raise the bottom of the pump room slab to avoid structural complications in present foundations. This new slab can span present pile caps and concrete beams. Existing foundations construction is ample to support new pump room loadings" (Carta de Strobel a Scott, op. cit., 15-11-1938.). "One which stands out because of its unusual character will be a mercury fountain, from which the precious metal, coveted by foreign invaders, will flow freely" (Preliminary Information..., op. cit., 22-12-1938). "An estimate will also be made on those items which are not ordinarily furnished by the Fair but will be in this case; such as, additional $3 \times 12$ joists 8 " on center to be placed under the fountain" (Carta del Ingeniero de la Exposición a Pomerance \& Breines, op. cit., 29-12-1938). "The Fair Corporation will construct the following items which are charged to the participant: Additional supports under the fountain and blocked up portion of the first floor occurring between Columns 83 and 84" (Carta de Roosevelt a De los Ríos, op. cit., 27-1-1939). NYPL.

${ }^{54}$ Carta de Larrea al Director del Musée de l'Homme, Palais du Trocadéro, París, 5-12-1938. AGA, Sec. AAEE, $54 / 11073$

55 Véase Cabañas Bravo, Miguel: Rodríguez Luna, el pintor del exilio republicano español, Madrid, CSIC, 2005, pp. 94-99. 
Associates, que tuvo lugar en la Feria entre mayo y octubre de 1939. En ella se vieron óleos de Goya, El Greco, Velázquez y Murillo, y Gregorio Marañón y José María Sert integraron, entre otros, su Comité Honorario ${ }^{56}$. En cuanto a la presencia de artistas contemporáneos destacó la labor de Salvador Dalí en la construcción del Pabellón de Venus ${ }^{57}$. El artista ampurdanés no había participado en la Exposición de París debido, según contaba Renau, a un incidente entre ambos causado por el arrebato de Dalí al saber que habían contactado antes con Picasso que con él para encargarle una obra para el Pabellón ${ }^{58}$. Quizás motivado por esta circunstancia y, sin duda, apoyado por la fama que buscaba ansiosamente entre el público neoyorquino, tramitó una participación independiente para realizar una llamativa intervención en la Feria.

En un último apunte nos gustaría lanzar una hipótesis que deberá ser contrastada en la medida en la que se vaya redescubriendo nueva documentación sobre la participación española en Nueva York. Se trata de la posibilidad de que se expusiera en el Pabellón de 1939 el Guernica de Picasso. Sabemos de la relación profesional y personal que tenía Juan Larrea con el artista malagueño, y ya hemos subrayado su labor en la organización de los materiales para la cita estadounidense. Si, por otro lado, pensamos que el cuadro, que había sido llevado de gira desde el final de la Exposición de París, llegó a Nueva York el 1 de mayo acompañado del propio Juan Negrín, quizás no es demasiado trivial preguntarse si, en el caso de que el Pabellón republicano se hubiese inaugurado, no habría contado con esta obra, propiedad de la República, como uno de sus mayores reclamos, como se buscó con la Fuente de Mercurio de Calder ${ }^{59}$.

\section{Los planes truncados}

Desgraciadamente, toda la estructura creada por el gobierno republicano, todos los planes y los proyectos de artistas, arquitectos e intelectuales para montar un nuevo escaparate mundial sobre la legalidad de la República, se desmoronaron al mismo tiempo que Franco proclamó su victoria. Aunque desde el primer momento el anuncio de participación en la Exposición había levantado ampollas entre el bando sublevado y el sector más conservador americano, la simpatía que le despertaba a Roosevelt la República había salvado situaciones delicadas, como la invitación oficial a la España de Franco, que se evitó argumentando que Estados Unidos sólo lo había ofrecido a los gobiernos con los que mantenía relaciones diplomáticas, a pesar de las protestas de la Falange ${ }^{60}$.

Sin embargo, paradójicamente, el trágico desenlace desde finales de 1938 parece no reflejarse en los preparativos del Pabellón, pues bien avanzados los primeros meses de 1939 es po-

56 McCall, George H. (ed.): Masterpieces of Art [cat. exp.], Nueva York, William Bradford Press, 1939.

57 Véase Salvador Dali: Dream of Venus [cat. exp.], Figueras, Fund. Gala-Salvador Dalí, 1999.

58 Véase Renau, Josep: "Albures y cuitas con el Guernica y su madre", manuscritos, Valencia, junio de 1981. Citado por CABañas Bravo, Miguel: "Renau y el Pabellón español de 1937 en París, con Picasso y sin Dalí”, en BRIhuega, Jaime y Piqueras, Norberto (eds.): Josep Renau 1907-1982: Compromís i cultura [cat. exp.], Valencia, Universitat de València y SECC, 2007, pp. 146-147.

59 Renau recordaba que la obra se exhibió en el MoMA a petición de Sidney Janis en beneficio de los refugiados españoles (Guernica - Legado Picasso, Madrid, MCU, 1981, pp. 16-18). Antes de ello, se expuso en la Valentine Gallery de Nueva York y realizó otra gira por Estados Unidos durante tres meses.

${ }^{60}$ Las quejas recibidas por la organización fueron muy numerosas, la mayoría argumentando su oposición a un gobierno comunista al que acusaban de quemar iglesias y matar a religiosos. NYWF 1939-1940. Cartas de la c. 1476, carp. 3-4. NYPL. También se pueden encontrar cartas de Falange Española pidiendo participar en un pabellón para la España franquista. Cartas de Joaquín Rodríguez de Cortazar, Jefe de Intercambio y Propaganda Exterior de Falange, Salamanca, 23-11-1937. NYWF 1939-1940. C. 1469, carp. 16. 13-1-1938. NYWF 1939-1940. C. 1503, carp. 1. NYPL. 
sible observar en la correspondencia el impulso por sacar adelante el proyecto. A finales de febrero, las cartas de los organizadores reclamaban a De los Ríos, entre otras cosas, un calendario con las fechas en que pensaban inaugurar las exposiciones de arte contemporáneo, la designación de su día nacional y los detalles de la iluminación externa de la fachada ${ }^{61}$. Incluso el 27 de febrero avisaban a la Embajada de Washington de que habían enviado un visado para Fernández Balbuena ${ }^{62}$.

A pesar de todo, el 7 de febrero, el mismo día en que Roosevelt le escribía a De los Ríos preguntándole cuándo sería definitivamente la inauguración del Pabellón español -prevista para el mes de mayo-, el embajador español hacía lo mismo reclamándole a Quintanilla el reingreso de los 6000 dólares entregados por adelantado para la realización de los cinco fres$\cos ^{63}$. Definitivamente, el 16 de marzo, Roosevelt le envió una invitación para visitar la Exposición a Juan de Cárdenas, el nuevo embajador del régimen franquista, adjuntándole una copia del contrato entre el gobierno de la II República y la organización de la Feria. El 3 de abril Whalen solicitó al Secretario de Estado que realizara esta gestión de manera oficial, ofreciendo el mismo espacio designado previamente para España ${ }^{64}$. Mientras tanto, retiraban el pase especial en la Exposición a Antonio de la Cruz Marín para entregárselo a Miguel Espinós, nuevo Cónsul General, a la vez que se nombraba a Alexander Weddell el Embajador de Estados Unidos en la España franquista y a H. Freeman Matthews, Encargado de Asuntos de Estados Unidos en San Sebastián ${ }^{65}$. Apenas diez días más tarde, el Gobierno de Burgos se pronunciaba a través de Cárdenas:

With reference to our conversations regarding the possibility that Spain would take part in he New York World's Fair, I beg to inform you that, according to instructions I have just received from Burgos, the Nationalist Government regrets not to be able to take part in such a magnificent exhibition because, apart from the shortage of time, all activity of my country is now fully concentrated on rapid reconstruction ${ }^{66}$.

Burgos tuvo que repetirlo más veces, pues la organización se resistía a no poder contar con las muestras del patrimonio español prometidas, a no poder terminar las obras ya avanzadas en el espacio GQ-7, por lo que se insistió en buscar distintas vías por medio de H. Freeman Matthews, en la embajada de San Sebastián ${ }^{67}$.

${ }^{61}$ Cartas de Roosevelt a De los Ríos, 20-2-1939, 24-2-1939. NYWF 1939-1940. C. 1503, carp. 1. NYPL.

${ }^{62}$ Carta de Lyon a Holmes, Nueva York, 27-2-1939. NYWF 1939-1940. C. 1503, carp. 1. NYPL.

${ }^{63}$ Carta de Roosevelt a De los Ríos, Nueva York, 7-3-1939. NYWF 1939-1940. C. 1503, carp. 1. NYPL. Carta de De los Ríos a Quintanilla, Washington, 7-3-1939. Citada en Los frescos de Luis Quintanilla..., op. cit., 2007, p. 53.

64 "In view of the few days remaining before the opening of the fair I am particularly anxious to see Spain represented among the other nations of the world at the New York World's Fair. I would appreciate it greatly, Mr. Secretary, if your office would extend an invitation to the present government of Spain to participate in the fair, the invitation to be issued in the same manner as the previous one sent to the former government. It is my understanding that the exhibit would be limited to the art of old Spanish painters". Carta de Whalen al Secretario de Estado, Nueva York, 34-1939. NYWF 1939-1940. C. 319, carp. 2. NYPL.

${ }^{65}$ Carta de Roosevelt a Cárdenas, Nueva York, 16-3-1939. Telegrama de Freeman Matthews a Whalen, San Sebastián, 20-4-1939. Carta de Roosevelt a Freeman Matthews, Washington, 29-4-1939. Carta de Wedden a Roosevelt, Virginia, 7-5-1939. Carta de Roosevelt a Raymon Hirt, Washington, 7-6-1939. NYWF 1939-1940. C. 1503, carp. 1. NYPL.

${ }^{66}$ Carta de Cárdenas a Roosevelt, Washington, 12-4-1939. C. 319, carp. 2. NYPL.

67 "We shall be grateful if at first opportunity you will be good enough to indicate to the Spanish government that the unit in hall of nations originally reserved for Spain is available stop Cardenas has sent detailed information stop we are convinced that this would be an excellent opportunity for the Spanish government to present an exhibit to some sixty million Americans who will visit the New York World's Fair". Telegrama de Whalen a Freeman Matthews, Nueva York, 20-4-1939. NYWF 1939-1940. C. 319, carp. 2. NYPL. 
El Ministerio de Asuntos Exteriores saluda atentamente a la Embajada de los Estados Unidos de América y se complace en acusarle recibo de su Nota Verbal n. ${ }^{\circ} 9$ del 20 del corriente, por la que tiene a bien transmitirle la invitación de la Presidencia de la Feria de New York para que España concurra en la misma.

El Gobierno nacional, al agradecer esta invitación y deferencia, de la que asimismo ha tenido conocimiento como se indica en dicha Nota por la detallada información recibida de su Representante en New York, siente vivamente que en atención a las circunstancias presentes y premura del tiempo disponible, no le sea posible participar en dicho certamen. Burgos, 26 de Abril de 1939.

Año de la Victoria ${ }^{68}$

Definitivamente, el proyecto del Pabellón español se dejaba en el tintero y se tiraba por tierra el trabajo de tantas personas a lo largo de varios meses, que quedaba inacabado o condenado al olvido durante varias décadas.

\section{Conclusiones}

En definitiva, la documentación encontrada no hace más que confirmar la existencia de un complejo proyecto del que, a buen seguro, se irán hallando nuevos datos que ayuden a arrojar luz a un tema del que todavía queda mucho por investigar. Según los datos expuestos, podemos establecer las siguientes conclusiones. En primer lugar, el Pabellón español de la Exposición Internacional de Nueva York de 1939 fue un proyecto aprobado por el Gobierno republicano en 1938 que no se llegó a inaugurar debido al reconocimiento del régimen de Franco por parte del Gobierno de los Estados Unidos, inmediatamente después de concluir la Guerra Civil. A pesar de las circunstancias poco favorables para la República y de la escasez de recursos que ya se tenían, el momento de mayor impulso a este proyecto tuvo lugar entre el otoño de 1938 y los primeros meses de 1939, lo que se puede interpretar como un último intento de llamada a la ayuda internacional y de supresión del pacto de no-intervención.

En segundo lugar, las características extraídas de la documentación encontrada muestran que el proyecto neoyorquino repitió los patrones utilizados en la Exposición Internacional de París de 1937, basados en el arte propagandístico y en la unión indisociable entre la tradición y la vanguardia. No obstante, se pueden matizar algunas diferencias que exponemos a continuación, que sirven de barómetro para medir la situación de España en ese momento. Por un lado, los requisitos de la exposición americana -que homologaban el espacio exterior, el aspecto de las fachadas y la decoración mural y escultórica-impidieron diseñar un edificio con tanta libertad como la que tuvieron, en su homólogo francés, Sert y Lacasa. Por otro lado, la orientación del Pabellón de Nueva York estuvo dirigida hacia el público estadounidense, lo que se deduce del lugar prioritario que iba a ocupar la Fuente de Mercurio de Calder y del homenaje de los frescos de Quintanilla a la Brigada Lincoln. Por último, el tono general de las obras que conocemos resulta mucho más rebajado, menos épico y combativo de aquél mostrado en París. Con la guerra casi perdida, las obras de Quintanilla y de Renau hablan de las consecuencias terribles de los conflictos bélicos y de las condiciones mínimas para un acuerdo de paz; el clasicismo y la mediterraneidad de Sunyer y Rebull parecen distar también del arrojo y la energía que buscaban las obras del 37.

\footnotetext{
${ }^{68}$ Copia de la carta del Ministerio de Asuntos Exteriores de España a la Embajada de Estados Unidos en San Sebastián, remitida por Warren Kelchner a Holmes, San Sebastián, 23-9-1939. NYWF 1939-1940. C. 1503, carp. 1. NYPL.
} 
En tercer lugar, la declinación de Franco a participar en Nueva York, una vez acabada la guerra, es la constatación de que el bando sublevado dio menos importancia a la propaganda en el exterior que el Gobierno republicano. Aunque la España franquista había intervenido con un pabellón en la Bienal de Venecia de 1938, quizás no vio ya necesario tomar el relevo para participar en la muestra estadounidense, una vez había sido reconocida por Roosevelt y por el sector más conservador de este país.

Como consecuencia de esta decisión de la diplomacia, la mayor parte de las obras pensadas para esta Exposición se han perdido o han sufrido el descuido y el olvido durante un largo periodo de tiempo. Además, todos los artistas, arquitectos e intelectuales que se implicaron en la organización de la participación española se verían empujados al exilio, la condena y la depuración. Se trata, pues, de un plan frustrado que ilustra cómo el impulso creador y renovador de la joven II República fue cercenado por el golpe franquista, que cortó las alas y dispersó al grupo que podría haber materializado uno de los grandes hitos del arte español en tiempos de guerra, probablemente muy similar al del Pabellón de 1937 -el del Guernica, la Montserrat, El segador-. Fue el último gran proyecto institucional de cara al exterior del Gobierno de la II República. La experiencia española en la Feria de Nueva York sólo fue una premonición más de lo que se avecinaba: el fracaso absoluto de la utopía de aquel Mundo del Mañana en el que las naciones del mundo convivirían en el respeto y en la paz.

Fecha de recepción: 10-II-2010

Fecha de aceptación: 26-II-2010 